\title{
RESEARCH ON VEIN FINDER INSTRUMENT DESIGN USING TWO- WAVELENGTH OPTICAL METHOD
}

\author{
Tran Van Tien, Huynh Quang Linh, Nguyen Anh Hang \\ University of Technology - VNUHCM \\ (Manuscript Received on April $5^{\text {th }}$, 2012, Manuscript Revised November 20 ${ }^{\text {rd }}$, 2012)
}

ABSTRACT: In intravenous injection manipulation, popular visual method of fast and accurate finding of veins strongly depends on patient body and physician experience. Especially for geriatric, pediatric or obese patients, nurses or paramedics may fail in the first intravenous injection and have to repeat many times, which causes a lot of pains or discomforts for the patients. This paper will introduce some studies on imaging of vein using two-wavelength optical method, on basis of which a vein finder instrument can be optimally designed for supporting intravenous injection manipulation.

Keywords: intravenous injection, vein finder, light tissue interaction, two-wavelength optical method.

\section{INTRODUCTION}

Injection needles are the most common and greatest source of procedural pain for patients, especially in pediatrics [1]. In quick immunizations, glucose monitoring, intravenous injection, laceration repairs, dermatologic procedures and even tattooing, needle pain is a major growing concern. These effects may be amplified with age, children avoid medical treatment, $16 \%$ to $75 \%$ of surveyed adults refuse to donate blood and geriatric patients refuse flu shots due to fear of needle pain $[2,3]$. The health implications of needle phobia extend beyond the affected individuals, HIV patients continued to infect others while delaying blood tests and needle phobic parents are less likely to immunize their children [4]. It is important to minimize the discomfort associated with needle injection for patients more than once; especially in intravenous injection manipulation. However, even skilled nurses or paramedics may be very often unsuccessful in such manipulation with obese, geriatric or pediatric patients, when their veins are not palpable or visible for popular visual finding. According to a recent study [5], it is estimated that there are nearly 500 million vein injections done every year with 92.5 to 97.3 percent successful in the first attempt, so that around 14 million cases are failed on the first try. The main reason is the vein invisibility due to factors like obesity and small sized veins. So research design of vein finder devices to support nurses in intravenous injection manipulation is really necessary. Moreover, those devices can be useful for physicians for locating and mapping the abnormal veins in treating disorders or diagnosing related diseases. 
Recently several devices have been developed to support physicians and nurses in finding veins for diagnosis or intravenous manipulation. Their principle of working is based on different capability of scattering and absorption of skin and vein to the light with different wavelength to show peripheral veins on the skin background [6, 7]. Mentioned devices are very compact and cause no damage to patients but require the ambient lighting not too bright in order to view the vein clearly. Some modern infrared imaging device with complex electronic system permits projecting of venous system contrast-enhanced images in real-time but they are very expensive. With other physical principle, high-resolution ultrasound scanner can provide good quality images of the superficial and deep veins for obese patients or small veins for pediatric patients in real-time as well. However, the transducer has to be held in place during needle insertion, which makes uncomfortable manipulation [8]. Venography provides an image of the veins after the patient is injected with a contrast dye. This x-ray image can be used for mapping veins in the body before surgery or treatment. Venography offers a wide field of view and is used for identifying and treating numerous disorders. There is however a significant amount of radiation associated with the procedure [9].

The purpose of this research is firstly quantitative study of the interaction of LED light with the tissue, on base of which optimal combination of LED wavelength should be chosen and secondly experimental verification of optimal layout of LEDs to design low cost vein finder instrument.

\section{METHODS}

\subsection{Simulation methods}

Photons transport in tissue may include mainly following processes: reflection, refraction, scattering and absorption. In order to examine the photon penetration in skin and veins, the Monte Carlo code for photon transport simulation MCML [12] has been used with the model of an infinitely narrow photon beam perpendicularly irradiating on the surveyed skins.

Table 1. Biological structure of surveyed skins [11]

\begin{tabular}{c|c|c|c}
\hline \hline \multicolumn{2}{c|}{ Skins with veins } & \multicolumn{2}{c}{ Skins without veins } \\
\hline Layer & Thickness & Layer & Thickness \\
\hline Epidermis & $0.06 \mathrm{~mm}$ & Epidermis & $0.06 \mathrm{~mm}$ \\
\hline Dermis & $5 \mathrm{~mm}$ & Dermis & $5 \mathrm{~mm}$ \\
\hline Blood & $1 \mathrm{~mm}$ & Subcutaneous & $7 \mathrm{~mm}$ \\
\hline Subcutaneous & $7 \mathrm{~mm}$ & & \\
\hline \hline
\end{tabular}


Model of skin (table 1) has 3-4 infinitely wide plane layers, which have characteristic parameters as the thickness, the refractive index $n$, the absorption coefficient $\mu_{\mathrm{a}}$, the scattering coefficient $\mu_{\mathrm{s}}$, and the anisotropy factor $\mathrm{g}$. The top ambient medium is air and bottom ambient medium is subcutaneous. Photon wavelength was selected in accordance to LED sources used in experimental procedure including 5 types: blue $(453.5 \mathrm{~nm})$, green $(515.8 \mathrm{~nm})$, orange $(593.4 \mathrm{~nm})$, red $(635.4 \mathrm{~nm})$ and IR (750nm).

\subsection{Experimental procedure}

In order to optimize geometric layout of LEDs to design appropriate projection area, some measurements were carried out to examine the effectiveness of human vision to above mentioned wavelengths, the relationship between the angle of illumination and scattering width in the dark room etc. General procedure is measuring intensity of reflecting light at various positions in dependence on different configurations of LEDs.

\section{RESULTS AND DISCUSSIONS}

\subsection{Simulation results}

Monte Carlo simulation was used to evaluate quantitatively two tasks: i) at which photon wavelength the absorption of blood is the highest, this result will help to select the appropriate LED to optimally distinguish the areas of veins and without veins, and ii) the scattering radius (the radial distance at which the light drops to $1 / \mathrm{e}$ of its original intensity) and absorption depth (the vertical distance into the material at which the light drops to 1/e of its original intensity), mentioned results will help to select optimal operating regime of LED.

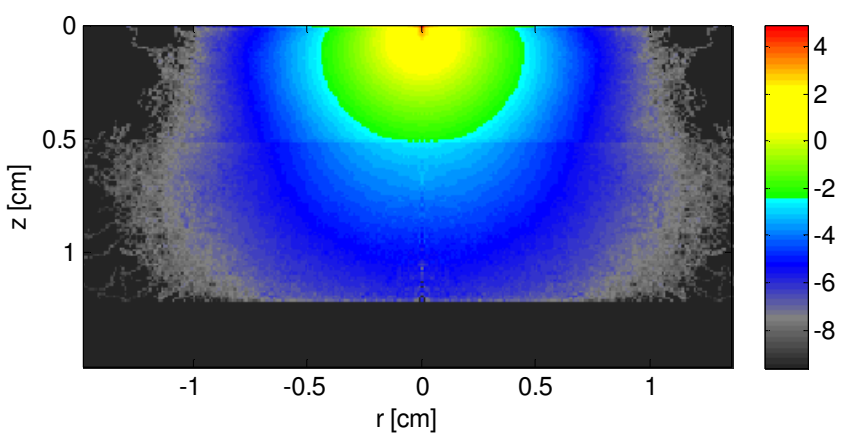

Figure 1. Internal photons distribution in tissue without veins with incident wavelength $634.5 \mathrm{~nm}$

Fig. 1 shows the photon distribution with incident wavelength $634.5 \mathrm{~nm}$ when they propagate in the tissue without veins. In this case, the scattering radius is approximately

$0.99 \mathrm{~cm}$ and the depth is about $1.21 \mathrm{~cm}$. 


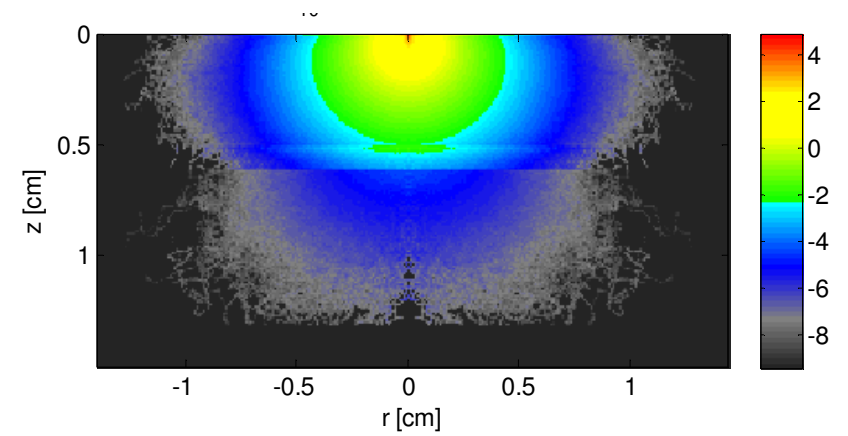

Figure 2. Internal photons distribution in tissue with veins with incident wavelength $634.5 \mathrm{~nm}$

Fig. 2 shows the photon distribution with incident wavelength $634.5 \mathrm{~nm}$ when they propagate in the tissue having veins. The photon distribution is clearly discontinued in the areas of depth from $0.506 \mathrm{~cm}$ to $0.606 \mathrm{~cm}$, where is the vein area. It has been reported that the blood in the veins absorbed a considerable part of photon beam. The reflected part on the skin surface decreases and as a result, the vein area will be seen darker than the surrounding with no vein. In addition, the scattering radius has no change and is a useful parameter to design the vein finder instrument.

For optimal selection of LED wavelength, mentioned photon-tissue-vein configuration was simulated for a set of wavelengths: blue $(453.5 \mathrm{~nm})$, green $(515.8 \mathrm{~nm})$, orange $(593.4 \mathrm{~nm})$, red $(635.4 \mathrm{~nm})$ and IR $(750 \mathrm{~nm})$. Calculated results are showed in Tab. 3.

Tab.3. MC simulation results for different lights reaching in the skin with vein and skin without vein

\begin{tabular}{cccccccc}
\hline \hline & \multicolumn{3}{c}{ Skin with vein } & \multicolumn{3}{c}{ Skin without vein } \\
\hline $\begin{array}{c}\text { Wavelength } \\
(\mathrm{nm})\end{array}$ & $\begin{array}{c}\mathrm{Z}_{\max } \\
(\mathrm{cm})\end{array}$ & $\begin{array}{c}\mathrm{r}_{\max } \\
(\mathrm{cm})\end{array}$ & $\begin{array}{c}\mathrm{R}\left(\mathrm{r}_{\max }\right) \\
\left(\mathrm{cm}^{-2}\right)\end{array}$ & $\begin{array}{c}\mathrm{A}(\mathrm{z}=0.506 \mathrm{~cm}) \\
\left(\mathrm{cm}^{-1}\right)\end{array}$ & $\begin{array}{c}\mathrm{Z}_{\max } \\
(\mathrm{cm})\end{array}$ & $\begin{array}{c}\mathrm{r}_{\max } \\
(\mathrm{cm})\end{array}$ & $\begin{array}{c}\mathrm{R}\left(\mathrm{r}_{\max }\right) \\
\left(\mathrm{cm}^{-2}\right)\end{array}$ \\
\hline 453.5 & 0.545 & 0.575 & $1.022 \mathrm{e}^{-8}$ & $2.638 \mathrm{e}^{-6}$ & 0.685 & 0.575 & $2.039 \mathrm{e}^{-9}$ \\
515.8 & 0.575 & 0.755 & $1.202 \mathrm{e}^{-9}$ & 0.0001323 & 1.025 & 0.785 & $4.475 \mathrm{e}^{-9}$ \\
593.4 & 0.615 & 0.895 & $1.061 \mathrm{e}^{-9}$ & 0.001074 & 1.215 & 0.945 & $1.397 \mathrm{e}^{-9}$ \\
635.4 & 1.315 & 0.945 & $2.72 \mathrm{e}^{-9}$ & 0.002109 & 1.215 & 0.995 & $1.134 \mathrm{e}^{-9}$ \\
750 & 1.315 & 1.265 & $3.35 \mathrm{e}^{-9}$ & 0.004726 & 1.215 & 1.185 & $9.301 \mathrm{e}^{-10}$ \\
\hline \hline
\end{tabular}

Where $z_{\max }$ is the absorption depth, $r_{\max }$ is the scattering radius, $\mathrm{R}\left(\mathrm{r}_{\max }\right)$ gives the reflectance at $r_{\max }, A(z=0.506 \mathrm{~cm})$ gives the photon probability of absorption in $\mathrm{z}$ layer of material.
Note that the instrument to locate a vein must be achieved two conditions: the contrast of a vein image can be viewed clearly and the illuminating space around the vein is large enough for access it. Thus the appropriate light has to satisfy: i) the penetration must overcome

\section{Trang 46}


the depth of the vein under the skin, so that the blood can absorb a great part of photons, ii) the scattering radius has to be large enough. Generally the veins are set up about $0.6 \mathrm{~cm}$ below the skin surface, results in Tab. 3 show that the light satisfying mentioned conditions are 750,635 and $593.4 \mathrm{~nm}$.

Furthermore because the human vision can detect the lights from 350 to $760 \mathrm{~nm}$ [15], the red and orange light can be considered to use. Scattering radius and penetration of both wavelengths are similar, but the absorption of blood for red light $\left(\mathrm{A}=0.002109 \mathrm{~cm}^{-1}\right)$ is higher than orange light $\left(\mathrm{A}=0.001074 \mathrm{~cm}^{-1}\right)$ and the reflectance of skin without vein for red light $\left(\mathrm{R}=1.134 \mathrm{e}^{-9} \mathrm{~cm}^{-2}\right)$ is smaller than orange light $\left(\mathrm{R}=1.397 \mathrm{e}^{-9} \mathrm{~cm}^{-2}\right)$. In addition, human eyes are more sensitive to the orange light than the red

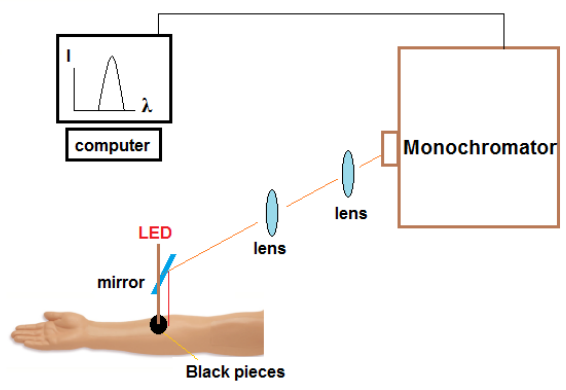

Figure 3. The optical system for measuring scattering radius

In the dim light condition, the visible scattering radius is considerably smaller then in the dark room condition. In practice, the vein finder instrument should be used in the light. The sensitivity to the orange light is about five times higher than the sensitivity to the red and violet light [16]. Thus, using the combination of orange and red light to manufacture the vein finder instrument will considerably enhance the view contrast.

\subsection{Experimental results}

Firstly, the experiment was designed for measuring of scattering radius depending on operating current of LED (Fig. 3). With circular black plastic rings around LED with the radius increasing by $1 \mathrm{~mm}$, the scattering radius in dependence on operating current of LED light $(635.4 \mathrm{~nm})$ irradiated perpendicularly to the skin with vein and without vein were measured [Fig. 4].

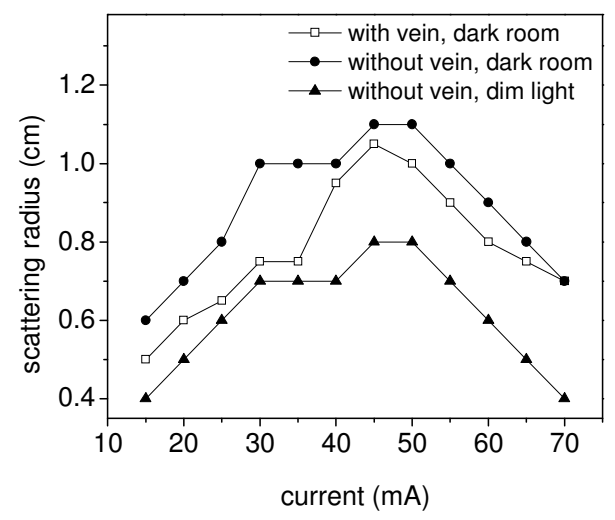

Figure 4. The scattering radius in dependence on LED current in dark room and dim light condition of normal light, so we need to shade the ambient light by any way to obtain optimal view of backscattering light from LED. 


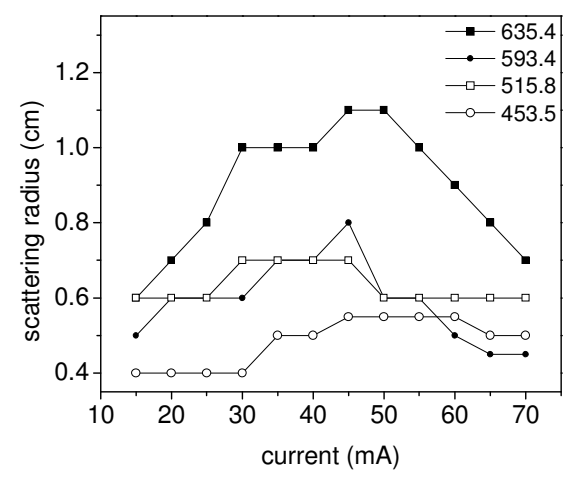

Figure 5. The scattering radius in dependence on LED current for different wavelengths in dark room condition

Fig. 5 shows that, the scattering radius with the light with the wavelength $635.4 \mathrm{~nm}$ is considerably greater then the others $(593 \mathrm{~nm}$, $515 \mathrm{~nm}, 453 \mathrm{~nm})$. Mentioned results are consistent with simulation. For the purpose of enhancing detection capacity of human eye the orange light with the wavelength $635.4 \mathrm{~nm}$ has been used as the optimal selection.

Figures 4 and 5 also shows, the optimal operating current of all measured LEDs to give the maximum scattering radius is about $45 \mathrm{~mA}$.

The relationship between the angle of irradiation and scattering radius shown on figure 6 was examined for the selection of the

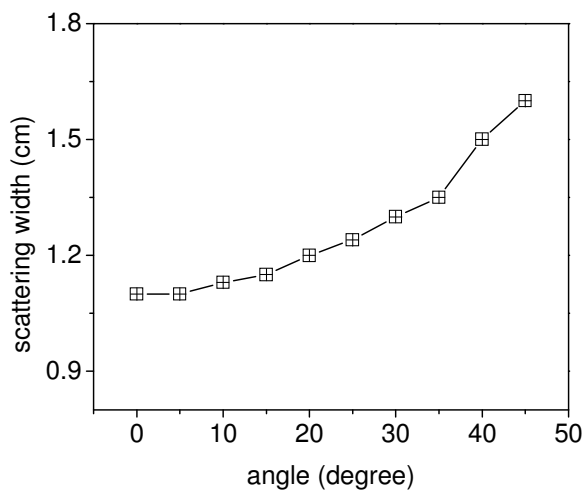

Figure 6. The scattering radius in dependence on irradiation angle of LED $653.4 \mathrm{~nm}$ operating on $45 \mathrm{~mA}$ current irradiated with different angles to the skin without vein.

optimal angle for LEDs layout in instrument design.

A prototype of vein finder instrument, which was designed and manufactured according to above mentioned results, is shown on the figure 7. Vein image could be seen clearly in normal ambient light. However, for the final product many aspects such as LED layout configuration, user-friendly flexible usage, stability and lastingness etc. have to considered more practically.

\section{Trang 48}



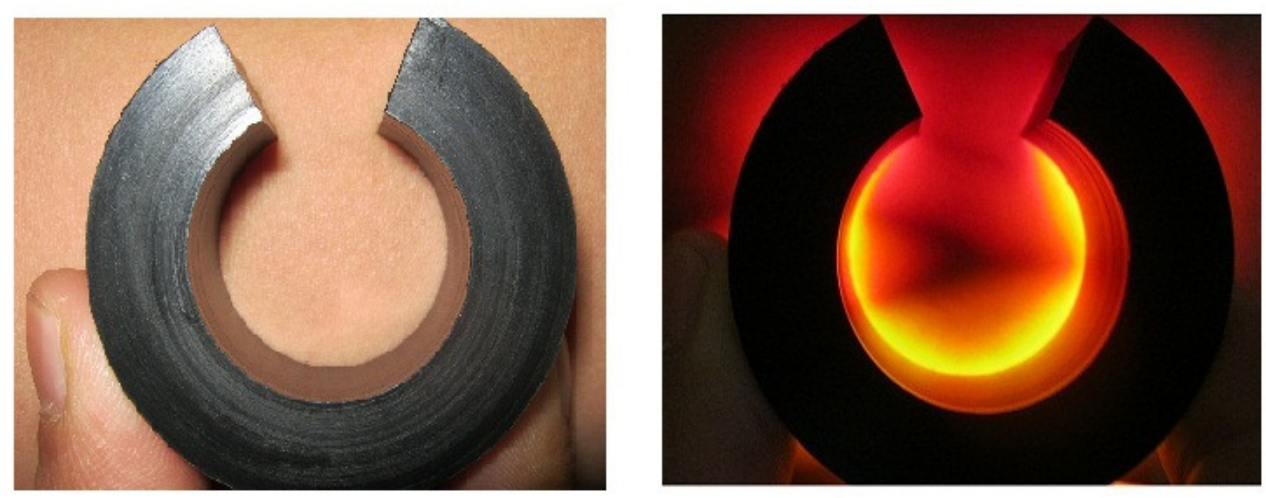

Figure 7. Prototype of vein finder instrument.

\section{CONCLUSION}

With the Monte Carlo simulation of lightskin-vein interaction, experimental verification and prototype manufacturing, some conclusions can be drawn as follows:

1. Simulation results of the interaction of LED light with the tissue by MCML are consistent with experimental results. This procedure can be used for further biomedical research using LED technology.

2. The optimal operating current of all measured LEDs to give the maximum scattering radius is about $45 \mathrm{~mA}$. The scattering radius in dependence on irradiation angle of LED can be used for LEDs layout design optimization.

3. There was found plausible scientific bases for using the combination between red and orange LEDs as an optimal solution for vein finding and imaging. This result similar as the design of foreign products (VeinLite, TransLite) confirmed the ability of domestically manufacturing with lower price. 


\title{
NGHIÊN CỨU CHẾ TẠO THIẾT BỊ TÌM TĨNH MẠCH BẰNG PHƯƠNG PHÁP QUANG HỌC KẾT HỌ̣P HAI BƯớC SÓNG
}

\author{
Trần Văn Tiến, Huỳnh Quang Linh, Nguyễn Ánh Hằng \\ Bộ môn Vật Lý Kỹ Thuật Y Sinh, Khoa Khoa học Ứng dụng, \\ Trường Đại Học Bách Khoa - ĐHQG TP.HCM
}

TÓM TÁT: Trong thao tác tiêm tĩnh mạch, việc xác định nhanh và chính xác vị trí tĩnh mạch thuờng phu thuộc rất lớn vào cơ thể bệnh nhân cũng nhu kinh nghiệm của các y bác sĩ. Đặc biệt đối với nhũng bệnh nhân lão khoa, bệnh nhi, hay bệnh nhân béo phì.., các y tá, y sĩ hay thất bại trong lần tiêm đầu tiên, phải tiêm lại nhiều lần gây đau đớn và cảm giác sọ hãi cho bệnh nhân. Bài viết này sẽ giới thiệu một số nghiên cứu trong việc xác định vị trí tĩnh mạch bằng phwơng pháp quang học kết hợp hai buớc sóng, trên cơ sở đó chế tạo thiết bị tối uu để hỗ trợ các thao tác tiêm tĩnh mạch đườc nhanh chóng, dễ dàng và chính xác.

\section{REFERENCES}

[1]. Schechter N.L, Zempsky W.T, Cohen L.L, McGrath P.J, Pain reduction during pediatric immunizations: evidence-based review and recommendations, Pediatr. Rev, 119, 1184 (2007).

[2]. Vika M, Raadal M, Skaret E, Kvale G, Dental and medical injections: prevalence of self-reported problems among 18-yr-old subjects in Norway, Eur J Oral Sci, 114, 122 (2006).

[3]. Harrington M, Sweeney M.R et. al, What would encourage blood donation in Ireland?, Vox Sang, 92, 361 (2007).

[4]. Froehlich H, West D.J, Compliance with hepatitis $B$ virus vaccination in a highrisk population, Aust. J. Physiother, 47, 179 (2001).
[5]. Ludeman K, Nursing Made Incredibly Easy!, 6, 5 (2008).

[6]. Lovhoiden G, Ph.D. Thesis, Design of a Prototype Vein Enhancing Illuminator, U.Tenn, Health Sci. Ctr., (2004).

[7]. Zeman H.D, Lovhoiden G, Vrancken C, Prototype vein contrast enhancer. SPIE, Bellingham, WA, 3949 (2004).

[8]. Kremkau F.W, Diagnostic ultrasound: principles, instruments and exercises, WB Saunders, Philadelphia, PA (2001).

[9]. Jackson T.R, Snell J.W, Goble J.C, Laws E.R, and Kassell N.F, Tissue Selective Magnetic Resonance Subtraction Venography. Proc. Spie, Medical Imaging, 2434, 300-306 (1995). 
[10]. Äulsbusch M.H, Häolscher D, and Blazek V, Spectral Monte-Carlo Simulations of Photon Penetration in Biotissue in Visible and Near Infrared, PIERS Proceedings, 483 - 487, Prague, Czech Republic (2007).

[11]. Nguyễn Trí Dũng, Mô Học. Nhà xuất bản y học, Tp - HCM, VN (2010).

[12]. Wang L.H, Jacques S.L, Zheng L.Q, MCML-Monte Carlo modeling of photon transport in multilayered tissues, Computer Methods Programs Biomed, 47:131-146, (1995).

[13]. Mobeley J, Dinh T.V, Optical properties of tissue. In T. V. Dinh, ed., Biomedical Photonics Handbook, SPIE Press, chapter 2 (2002).

[14]. Matjaz L, Zdenko V, Zabkar J, Pirnat S, QCW Pulsed Nd:YAG $1064 \mathrm{~nm}$ Laser Lipolysis. LAHA, 1, p24-34 (2010).

[15]. Michael F, Deering, The Limits of Human Vision. $2^{\text {nd }}$ International
Immersive Projection Technology Workshop (1998).

[16]. Gubisch R.W, Physiology J, Optical Performance of the Human Eye. JOSA, Vol. 57, Issue 3, pp. 407-415 (1967).

[17]. Peter G, Barten J, Human vision. Proc. SPIE 1666, 57 (1992).

[18]. Veinlite ${ }^{\circledR}$ is the Leader, Transillumination Vein Access, Viewed 29/9/2012, http://www.veinlite.com/.

[19]. Veinlite LED Rechargeable Transilluminator Vein Finder, Viewed (2012). http://www.balkowitsch.com/ProductID2732-ProductDetails.aspx. 